\title{
Has monitoring failed the Olifants River, Mpumalanga?
}

\author{
S de Villiers ${ }^{1 *}$ and ST Mkwelo ${ }^{2}$ \\ ${ }^{1}$ AEON, University of Cape Town, Rondebosch 7701, South Africa \\ ${ }^{2}$ Department of Geology, University of Fort Hare, Alice 5700, South Africa
}

\begin{abstract}
Water quality monitoring in the Olifants River catchment, Mpumalanga, is evaluated using river water dissolved sulphate levels, one of the best indicators of pollution related to acid mine drainage. Assessment of long-term water quality records shows that monitoring has not been carried out systematically. In that it fails one of the most fundamental criteria of good environmental monitoring practices. At some monitoring stations sampling frequency has been scaled down from approximately weekly to monthly intervals over time, despite evidence for increasing and problematic levels of pollution. At the Loskop Dam dissolved sulphate levels have increased more than 7-fold since the 1970s evidently due to increasing levels of pollution within the Little Olifants River catchment. At 4 of the 7 long-term monitoring stations river water sulphate levels exceed the $100 \mathrm{mg} / \ell$ threshold value for aquatic ecosystem health most of the time for the duration of the record, and all of the time since about 2001. At these stations river water sulphate levels also exceed the $200 \mathrm{mg} / \ell$ threshold for human consumption 27 to $45 \%$ of the time, for the duration of the long-term record. These observations necessitate more frequent and improved monitoring, not evidently reduced efforts. A major concern is the location of a recently re-opened copper mine outside Phalaborwa, just upstream from the confluence of the Ga-Selati River and the Olifants River. Levels of copper sulphate, highly toxic to aquatic species, should be urgently investigated as a probable cause of recent fish and crocodile deaths in the Kruger National Park. In river systems subject to intensive mining activity, such as the Olifants River, toxic constituents such as copper, arsenic, chrome-VI, etc., currently not routinely measured by the Department of Water Affairs (DWA) need to be included in monitoring efforts as a matter of urgency. This will require drastic improvements in current water quality monitoring efforts, including the acquisition of modern analytical instrumentation.
\end{abstract}

Keywords: Olifants River, Mpumalanga, dissolved sulphate, monitoring

\section{Introduction}

The Olifants River in Mpumalanga is presently one of the most threatened river systems in South Africa (Van Vuuren, 2009; Ballance et al., 2001). Reports of unexplained fish and crocodile deaths within the catchment, including recently in the Kruger National Park have abounded for several years and have received a fair amount of attention, including the establishment of the 'Consortium for the Restoration of the Olifants Catchment' initiative (Van Vuuren, 2009). Despite obvious signs that water quality in the Olifants River has been deteriorating as a result of industrial, mining and agriculture activities, the trigger for episodic fish and crocodile deaths in the river system remains elusive. This raises serious concerns about the adequacy of monitoring efforts in the Olifants River system.

Environmental monitoring is the repetitive and systematic measurement of environmental characteristics, with the purpose of testing hypotheses of the effects of human activity on the environment. This requires the design of scientifically robust sampling and measurement programs, based on testable hypotheses, which involve repetitive sampling over an appropriate period of time. The detection of temporal and/or spatial differences is the most basic requirement of an environmental monitoring programme. With this in mind, this study evaluates water quality monitoring in the Olifants River, based on

\footnotetext{
* To whom all correspondence should be addressed.

용 +2773-228 1133; fax: +2786-623 4586;

e-mail: steph.devilliers@gmail.com

Received 28 October 2008; accepted in revised form 14 August 2009.
}

consideration of one water quality parameter only, dissolved sulphate $\left(\mathrm{SO}_{4}^{2-}\right)$ levels.

The motivation for the simplistic approach adopted in this evaluation of monitoring in the Olifants River system is severalfold: elevated dissolved sulphate levels are indicative of pollution related to acid mine drainage (Anderson et al., 2000). The dissolved sulphate derives from the oxidation of metal sulphides such as pyrite, abundant in, for example, coalrich lithologies and precious metal-rich deposits. This makes dissolved sulphate levels ideal for testing hypotheses such as that deteriorating water quality in the Olifants River is attributable to gold- and coal-mining activities in the upper catchment. Additionally, dissolved sulphate, unlike trace metals such as iron, is conservative at the concentrations and $\mathrm{pH}$ conditions observed in river systems, meaning it is not removed from solution through precipitation or reactions with other components (Anderson et al., 2000). Also, dissolved sulphate is relatively easy to measure, which ensures robust long-term data records. These characteristics of river water sulphate all contribute to making it ideal for the detection of temporal and spatial differences in water quality related to acid mine drainage within a catchment such as the Olifants River.

\section{Water quality monitoring in the Olifants River: Sampling location and frequency}

The Olifants River has a catchment size of about $54750 \mathrm{~km}^{2}$, a mean annual runoff of $2400 \times 10^{6} \mathrm{~m}^{3}$ and is subject to intensive mining activities in most of its 9 secondary catchments (Fig. 1). The catchment is monitored by the National Chemical Monitoring Programme, with the aim to 'provide data and information on the surface inorganic chemical water quality of 


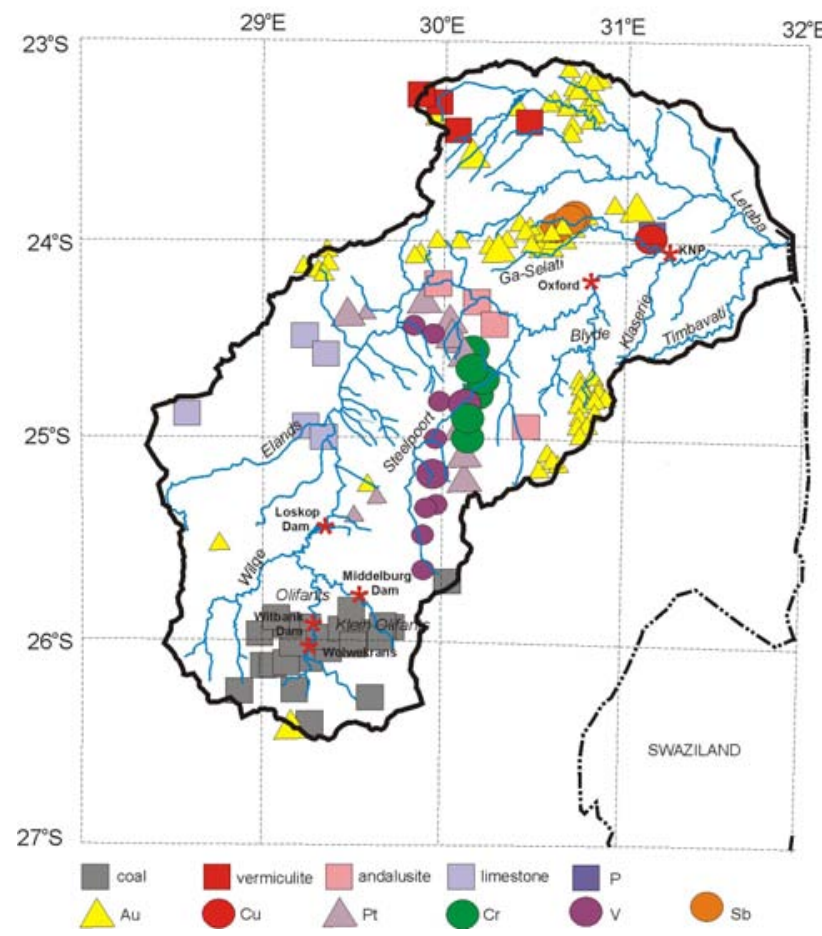

Figure 1

The Olifants River catchment in Mpumalanga, South Africa. Long-term water quality monitoring stations of DWAF

(Department of Water Affairs and Forestry) are indicated by red * symbols. Also given are the names of the main tributaries of the Olifants River, and the location of mining activities. Large symbols indicate currently active mines, and small symbols inactive mines.

South Africa's water resources' (DWA, 2009). The National Toxicity Monitoring Programme, still in the developmental stage, will aim to measure and assess the status of and trends in potentially toxic substances in South Africa's water resources. The Directorate Water Quality Management, which oversees the NCMP and NTMP, and Regional Offices of the national Department of Water Affairs and Forestry, now the Department of Water Affairs, are jointly responsible for water quality in South Africa, in terms of Act 108 of 1996 of the Constitution of the Republic of South Africa (Statutes of the Republic of
South Africa - Constitutional Law, 1996). The main objectives of the Water Quality Management Directorate include ensuring sustainable water quality management through source- directed controls and remediation-directed measures. River water quality data are available through the Resource Quality Services (DWA, 2009).

Data for 7 long-term monitoring sites in the Olifants River catchment were obtained for the purposes of this study (Fig. 1, Table 1). These include 2 stations in the upper reaches of the Olifants River and one on the Little Olifants River tributary, all in areas subject to intensive coal mining activities (Fig. 1). The ecological status of the Olifants River in this region has been classified as 'poor to unacceptable' (Ballance et al., 2001). The Loskop Dam monitoring stations are downstream from the confluence with the Wilge River, with a 'good to fair' ecological status, despite problems with mine effluent draining into the Wilge River tributary, and increasingly frequent fish deaths in the Lopkop Dam. Further downstream is the Oxford monitoring station, situated after the confluences with the Elands, Steelpoort and Blyde River tributaries (Fig. 1). The ecological status of the Elands River is poor to unacceptable, attributable largely to commercial agricultural activities. The Steelpoort River is in a 'fair to unacceptable' state. The Blyde River, which joins the Olifants River just upstream from the Oxford monitoring station, is in a 'good to natural' ecological state and generally improves water quality in the Olifants River downstream of their confluence (Ballance et al., 2001). The lowermost long-term monitoring station is at the Kruger National Park (KNP), just downstream of the confluence with the Ga-Selati River, which is in a 'fair to poor' state.

Most of the data sets are several decades long (Table 1). However, with the exception of the Middelburg Dam sampling station, where monitoring has been conducted at weekly intervals for most of the data record (Fig. 2), sampling frequency has been erratic and does not meet the fundamental requirement of environmental monitoring, that is systematic repetitive sampling. At the Wolwekrans, Witbank Dam and Oxford monitoring stations, sampling frequency has declined from highs of weekly, to twice a month or less. Sampling has been even more erratic at the Loskop Dam and Kruger National Park monitoring stations, which are currently being sampled at frequencies of monthly or less. Ironically, the latter 2 locations are most relevant to elucidating the increasing frequency of fish and crocodile deaths in the Olifants River system. From

\begin{tabular}{|c|c|c|c|c|c|c|c|}
\hline $\begin{array}{r}\text { Location of long } \\
\text { maximum } \mathrm{SO}_{4}{ }^{2-} \text { cor } \\
\text { respe }\end{array}$ & $\begin{array}{l}\text { erm water qu } \\
\text { entrations al } \\
\text { tively. } \mathrm{N} \text { is tl }\end{array}$ & $\begin{array}{l}\text { dity monit } \\
\text { d percenta } \\
\text { total num }\end{array}$ & $\begin{array}{c}\text { Table } 1 \\
\text { ing stations } \\
\text { e of measur } \\
\text { er of measu }\end{array}$ & $\begin{array}{l}\text { on the Olifa } \\
\text { ements with } \\
\text { rement point }\end{array}$ & $\begin{array}{l}\text { nts River; me } \\
\text { values excee } \\
\text { ts in the data }\end{array}$ & $\begin{array}{l}\text { dian, minin } \\
\text { ding } 100 \text { ar } \\
\text { records. }\end{array}$ & $\begin{array}{l}\mathrm{um} \text { and } \\
200 \mathrm{mg} / \mathrm{e}\end{array}$ \\
\hline Monitoring Station & Wolwekrans & $\begin{array}{l}\text { Witbank } \\
\text { Dam }\end{array}$ & $\begin{array}{l}\text { Middelburg } \\
\text { Dam }\end{array}$ & \begin{tabular}{|c|} 
Loskop Dam \\
- Wall
\end{tabular} & $\begin{array}{c}\text { Loskop Dam } \\
\text { - Canal }\end{array}$ & Oxford & Kruger N.P. \\
\hline Latitude & -26.006 & -25.892 & -25.773 & -25.417 & -25.417 & -24.184 & -24.059 \\
\hline Longitude & 29.254 & 29.304 & 29.544 & 29.358 & 29.358 & 30.824 & 31.237 \\
\hline Monitoring period & 1979-2006 & $1983-2006$ & 1983-2006 & $1968-2004$ & $1975-2004$ & $1975-2006$ & $1983-2006$ \\
\hline $\mathbf{N}$ & 816 & 554 & 1024 & 403 & 512 & 707 & 644 \\
\hline Concentration $\left(\mathrm{mg} \mathrm{SO}_{4}\right.$ & & & & & & & \\
\hline Minimum & 16 & 34 & 32 & 5 & 7 & 2 & 3 \\
\hline Maximum & 1549 & 300 & 1185 & 190 & 188 & 944 & 1288 \\
\hline Median & 175 & 165 & 162 & 68 & 79 & 20 & 103 \\
\hline$\%$ of $\mathrm{N}>100 \mathrm{mg} / \mathrm{l}$ & $75 \%$ & $92 \%$ & $93 \%$ & $18 \%$ & $29 \%$ & $<1 \%$ & $52 \%$ \\
\hline$\%$ of $\mathrm{N}>200 \mathrm{mg} / \mathrm{l}$ & $45 \%$ & $27 \%$ & $32 \%$ & $0 \%$ & $0 \%$ & $<1 \%$ & $38 \%$ \\
\hline
\end{tabular}



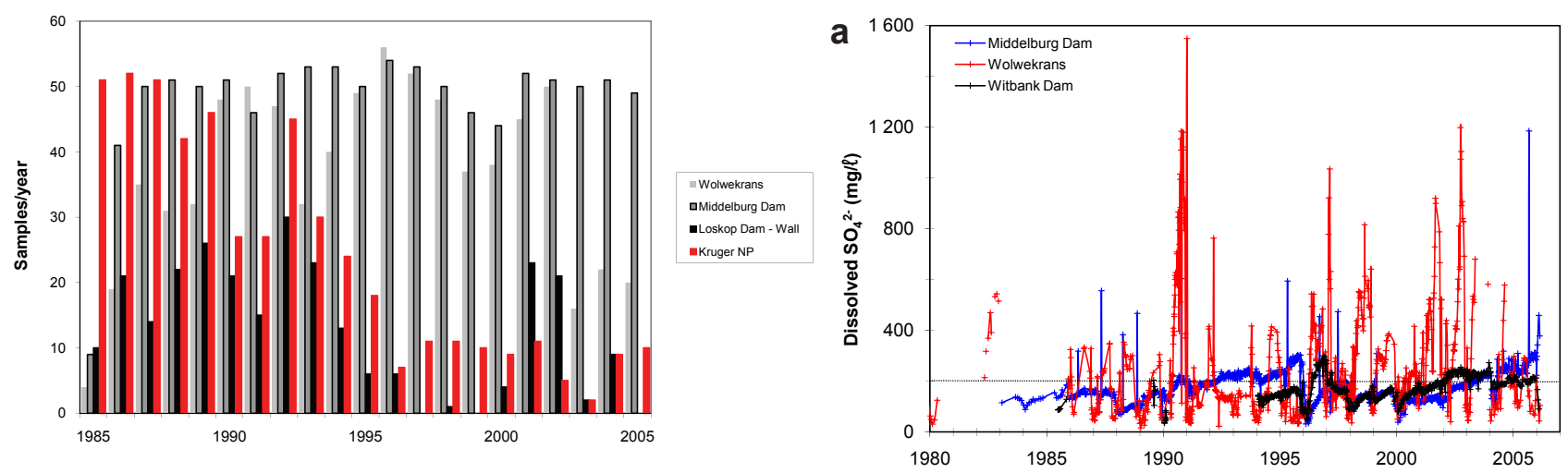

Figure 2

Sampling frequency at four of the long-term water quality monitoring stations on the Olifants River

an environmental monitoring point of view, the reduction in sampling frequency at all but one of the Olifants River stations does not make sense and if a change in sampling frequency was warranted, it must have been towards increasing or maintaining sampling frequency.

\section{Spatial trends in river dissolved $\mathrm{SO}_{4}{ }^{2-}$ in the Olifants River catchment}

An often-repeated statement made in regards to water quality in the Olifants River is that water quality parameters are within acceptable levels. According to the South African Water Quality guidelines (DWAF, 1996a), the target water quality range (TWQR) for dissolved sulphate is below $200 \mathrm{mg} / \ell$ for human consumption. This is similar to the maximum contaminant levels prescribed by the Environmental Protection Agency in the USA and the European Union (WHO, 2004). There is no prescribed TWQR value available for aquatic ecosystems in the South African water quality guidelines (DWAF, 1996b). However, aquatic ecosystems are almost without exception more sensitive than humans to environmental pollutants and as a result TWQR values, where available, are usually lower. Maximum dissolved sulphate levels of $100 \mathrm{mg} / \ell$ have been proposed for aquatic ecosystems in for example Canada (Ministry of Environment, Lands and Parks, Province of British Columbia, 2000).

Within the Olifants River system the highest river water sulphate concentrations are observed at the Wolwekrans monitoring station, the furthest upstream site (Table 1, Fig. 3). This station is located in the area of most intense coal mining activity in Mpumalanga. The maximum value observed at Wolwekrans, $1549 \mathrm{mg} \mathrm{SO}_{4}^{2-1} \ell$, is more than 7 times the TWQR value, and almost 100 times higher than the lowest value observed, $16 \mathrm{mg} / \ell$, with the latter value indicative of previous relatively unpolluted conditions at this site (Table 1). The high values are diluted to lower values at Witbank Dam further downstream, and to an even more significant extent by the time it reaches the Loskop Dam (Fig. 3; Table 1). Between the Loskop Dam and Oxford Stations, dilution by rivers such as the relatively pristine Blyde River (Fig. 1) results in a further reduction in sulphate levels, by a factor of more than 3 (Table 1, Fig. 3).

One of the most interesting features of the long-term monitoring data is comparison of sulphate level at the Oxford Station in the middle reaches of the Olifants River, with that further downstream site at the KNP (Fig. 3). The much higher sulphate values observed at the KNP site, most pronounced

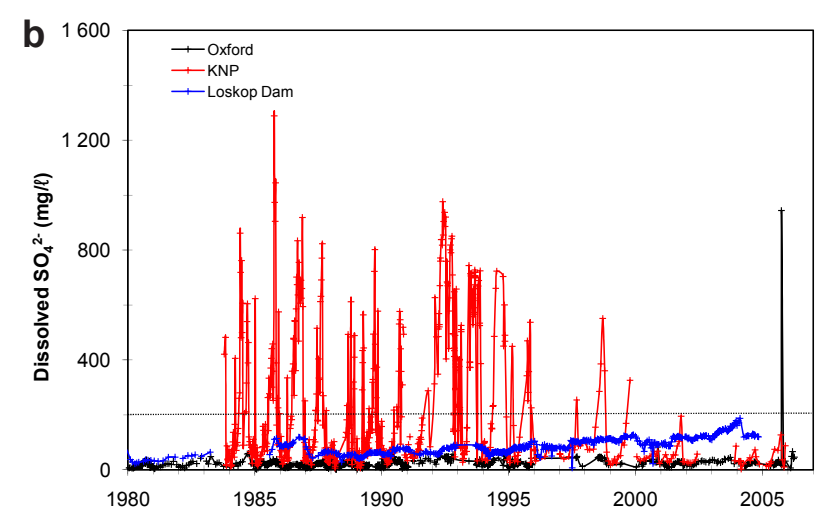

Figure 3

Long-term dissolved sulfate trends for river water at six monitoring sites on the Olifants River, (a) at Wolwekrans, Witbank Dam and Middelburg Dam in the upper reaches, and (b) Loskop Dam, Oxford and the Kruger National Park in the middle and lower reaches. The line at $200 \mathrm{mg} / \mathrm{l}$ indicates the threshold value for human consumption.

during the 1980 s to 1990 s, indicate a significant source of river water sulphate in the lower reaches of the Olifants River. The high sulphate values at the KNP station, in fact, are exceeded only by values observed at Wolwekrans (Table 1). The most likely source of the elevated sulphate levels observed at KNP is the Ga-Selati River (Fig. 1) and more specifically, copper and other mining activities at the Palabora Mining Company (Ltd.), just upstream of the KNP (Fig. 4).

Despite encouraging evidence for dilution of high sulphate levels within the Olifants River system, unacceptably high levels are observed at almost all of the monitoring stations. The values observed, specifically at the Wolwekrans and KNP Stations, are equivalent to those measured in mine leachates (Hammarstrom et al., 2005) and rivers considered the most polluted in Europe (Majer et al., 2005; Monteith and Evans, 2005). It is difficult to envision a source for these high sulphate levels, other than acid mine drainage. Values exceeding the threshold value of $200 \mathrm{mg} / \ell$ for human consumption are observed at all of the stations, with the exception of the Loskop Dam (Table 1). This threshold is exceeded for $45 \%$ of the observations at Wolvekrans, and 27 to $38 \%$ of the time at 3 of the other stations: Witbank Dam, Middelburg Dam and the KNP site. Even more problematic is the percentage of time that dissolved sulphate exceeds the proposed $100 \mathrm{mg} / \ell$ threshold value for aquatic ecosystem health, the most problematic being the Middelburg Dam (93\%), Witbank Dam (92\%), Wolwekrans (75\%), KNP (52\%) and Loskop Dam (18 to 29\%). 


\section{Temporal trends in river dissolved $\mathrm{SO}_{4}{ }^{2-}$ in the Olifants River catchment}

A pronounced seasonal cycle with high sulphate levels during the August-October late winter period, i.e. towards the end of the dry season, is apparent at all of the stream-monitoring stations (Wolwekrans, Oxford and KNP; Figs. 3 and 5). This also coincides with the time when most episodes of fish and/ or crocodile deaths have been reported. Although there are indications of a similar seasonal cycle at the dam stations, the amplitude is reduced, as a result of mixing within the dam systems. Superimposed on these seasonal cycles are long-term trends (Fig. 3). Unfortunately, one of the most problematic aspects of non-systematic sampling is its negative impact on rigorous statistical long-term trend analysis.

The most pronounced increase in sulphate levels is observed at the Loskop Dam (Fig. 6). Although sulphate levels in the Loskop Dam are still low relative to those observed at most of the other stations, it has increased by a factor of more than 7 since the 1970s. Importantly, levels have consistently been above the $100 \mathrm{mg} / \ell$ aquatic ecosystem threshold value since 2001. A similar consistent increase is observed at the Middelburg Dam (Fig. 3), where values have increased more than 3-fold since 2001. Additionally, values at this site have been persistently above the $200 \mathrm{mg} / \ell$ threshold for human consumption since 2004. Values at the Witbank Dam, in contrast, have been relatively stable over this time period. The implication, in the absence of long-term monitoring data for the Wilge River, is that increasing sulphate levels in the Loskop Dam have their origin in the Little Olifants River, the catchment area of the Middelburg Dam (Fig. 1).

Dissolved sulphate levels at the downstream Oxford Station have been relatively stable and below $100 \mathrm{mg} / \ell$, with the exception of a spike $(944 \mathrm{mg} / \ell)$ observed on 29 September 2005 (Fig. 3). This is the only spike of this magnitude observed at the downstream Oxford Station. Worryingly, it was observed several weeks after a similar spike at the Middelburg Dam (2 September 2005, Fig. 3), more than $300 \mathrm{~km}$ upstream. The time-lapse between these 2 spikes is consistent with the measured rate of river flow between these 2 sites. Unfortunately, there are no data available over this time period at the intermediate station, Loskop Dam, a result of the non-systematic sampling frequency. If the spike observed at the Oxford Station on 29 September 2005 is a remnant of the spike observed at the Middelburg Dam on 2 September 2005, it has disconcerting implications for the ability of such a pollution pulse to travel almost the entire length of the Olifants River.

Although sulphate levels at the KNP Station appear to have declined since 1995 (Fig. 3), this observation may be an artefact of the dramatic reduction in sampling frequency since then (Fig. 2). As mentioned in the previous section, these very high sulphate levels observed at the KNP Station compared to the Oxford Station imply a significant source of sulphate (and other water components) between these 2 sites. The mostly likely source of this sulphate is the activities of the Palabora Mining Company (Pty.) just upstream (less than $10 \mathrm{~km}$ ) from the confluence of the Olifants River with the Ga-Selati River (Fig. 4). This includes the largest open-pit copper mine in the world, in addition to the most productive phosphate mine in South Africa. Open-pit copper mining ceased at this site in 2002 and has been replaced by underground mining, which commenced in 2005 (Palabora Mining Company, 2005). In addition to mining, smelting and refining of copper are carried out on site. The most relevant by-product of these activities is $\mathrm{CuSO}_{4}$ (copper $31^{\circ} \mathrm{E}$

$24^{\circ} \mathrm{S}$

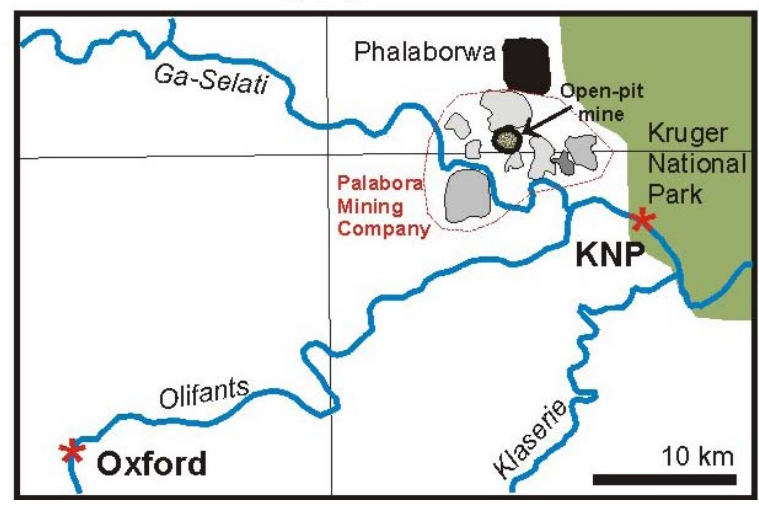

Figure 4

Confluence of the Olifants River and the Ga-Selati River, downstream from Phalaborwa and the Palabora Mining Company copper mine. Also shown are the two downstream $D W A F$ water monitoring stations

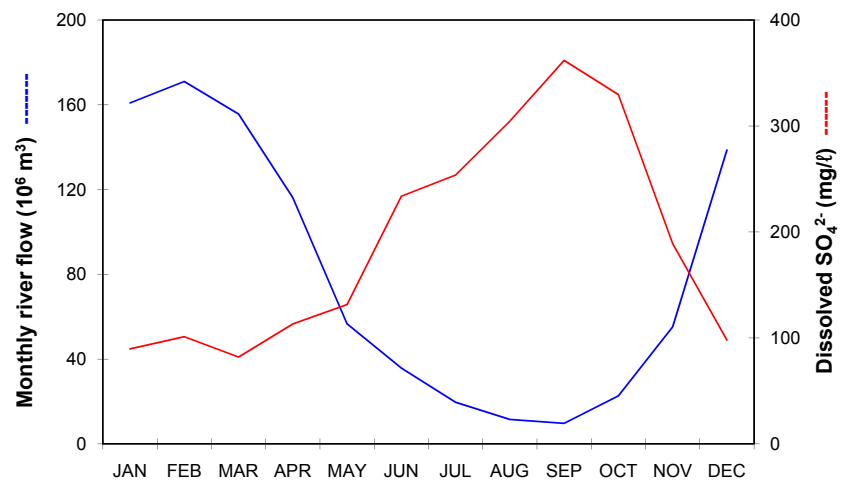

Figure 5

Seasonal profiles for river flow and river dissolved sulphate levels at the KNP Station, obtained from average monthly values calculated from long-term monitoring data

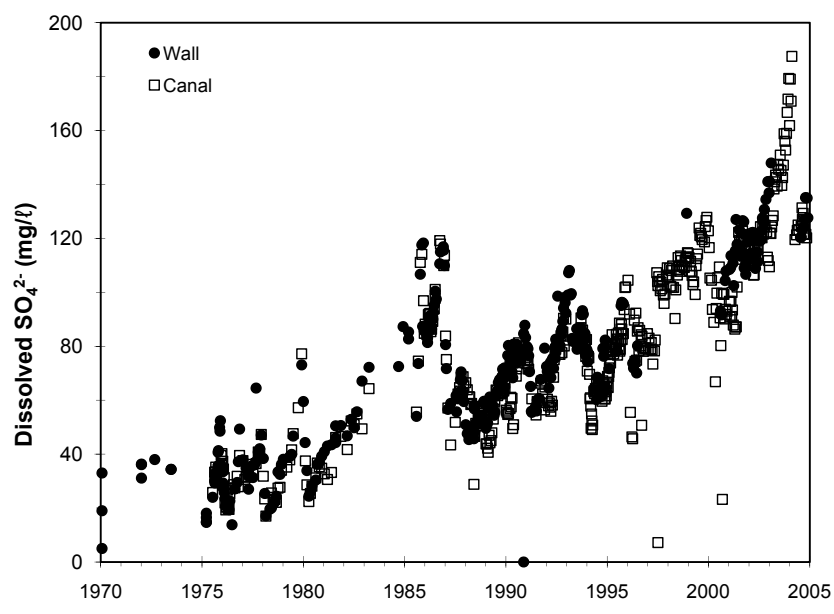

Figure 5

Trends in river water dissolved sulfate levels at the two Loskop Dam monitoring stations

sulphate). This, combined with changes in the extent of mining operations, may explain the temporal trends and high levels of river water sulphate at the KNP Station. However, this cannot be assessed, as no published long-term water quality data are 
available downstream from the mining activities, before the confluence of the Ga-Selati River with the Olifants River.

Copper mining activities on the Ga-Selati River, just upstream of the KNP monitoring site are important and relevant for another reason. Copper sulphate is highly toxic to fish and also invertebrates such as crabs and shrimps (Chen and Lin, 2001; Reardon and Harrell, 1990; Taylor et al., 1995; Torres et al., 1987). It is classified as a highly toxic substance, because of its harmful effects on aquatic species and also humans. As a result, its use as a pesticide to control bacterial and fungal diseases in the agricultural sector is controversial and questionable (Ahmed and Shoka, 1994). The South African TWQR for water copper levels is $<1 \mathrm{mg} / \ell$ for drinking water and $<0.3$ and 1.2 to $1.4 \mu \mathrm{g} / \ell$ for soft and hard water aquatic ecosystems, respectively (DWAF, 1996a;b). These TWQR values (and those for other toxic water constituents such as lead, arsenic, chrome-VI etc.) are meaningless, however, if copper measurements are not carried out routinely as part of DWA's water quality monitoring programme. Dissolved copper levels far in excess of these TWQR values have, however, been reported in the scientific literature, in the proximity of mining areas in the Witwatersrand area (Naicker et al., 2003) and near the relatively unpolluted Oxford Monitoring Station (Botes and Van Staden, 2005).

The recent resumption of copper mining activities in close proximity to the KNP may very well be the smoking gun in the search for the cause of the recent fish and crocodile deaths in the Kruger National Park. However, the data required to test this hypothesis do not exist, yet. Measurement of heavy metal concentrations at very low levels $(<1 \mathrm{mg} / \ell$ or less) requires very sensitive instrumentation, such as ICP-MS (inductively coupled plasma mass spectrometry) and thorough sampling protocols. It is cause for concern and a situation in need of urgent attention that modern tools such as ICP-MS do not play a role in routine water quality monitoring in South Africa yet, particularly in areas impacted on by mining activities.

\section{Conclusions}

One of the most disconcerting aspects of the Olifants River long-term water quality data is the non-systematic nature thereof, especially in light of clear evidence for dramatically worsening conditions. Monthly sampling frequencies will capture pollution events of short duration by chance only. A $2^{\text {nd }}$ major concern is that current monitoring efforts do not include routine measurement of toxic substances such as heavy metals in mining areas, or pesticides in agricultural areas. Most of the water quality parameters currently measured routinely are very interesting from a geochemical point of view (e.g. major cations and anions and alkalinity), but is of much less relevance to human health and environmental issues than trace levels of toxic substances. This, together with non-systematic sampling strategies and the absence of monitoring at several key sites, such as in close proximity of point sources such as the Palabora Copper Mine, makes it difficult to test hypotheses and to pinpoint the exact sources of increasing pollution in the Olifants River system.

It is true that there are "uncertainties regarding the relationship between concentrations of the substances in the water and their health effects' (Kempster et al., 2007). It is also true that most South African water quality guideline values are not as stringent as those adopted by developed countries. It can be argued that water quality guidelines in developing countries such as South Africa should in fact be more stringent, to safeguard the well-being of generally poorer and less healthy human populations. Are the relevant authorities carrying out research to reduce these 'uncertainties' (Kempster et al., 2007), and on which side of these uncertainties do we choose to err? It is true that improved water quality monitoring programmes will have significant cost implications, both in 'instrumentation needed for monitoring and analysis', 'as well as trained operators' (Kempster et al., 2007). It is also true that the cost implications of environmental remediation will be even more substantial, and the cost to ecosystem and human health, immeasurable.

\section{References}

AHMED HMS and SHOKA AEA (1994) Toxic interactions between copper sulphate and some organic agrochemicals. Toxicol. Lett. 70 (1) $109-119$.

ANDERSON RM, BEER KM, BUCKWALTER TF, CLARK McAULEY SD, SAMS JI III and WILLIAMS DR (2000) Water quality in the Alleghenyand Monongahela River Basins Pennsylvania, West Virginia, New York, and Maryland, 1996-98. US Geological Survey Circular 1202, 32 http://pubs.water.usgs. gov/circ1202.

BALLANCE A, HILL L, ROUX D, SILBERBAUER M and STRYDOM W (2001) State of the Rivers Report: Crocodile, SabieSand and Olifants River Systems. Resource Quality Services, DWAF, Pretoria, South Africa Www.csir.co.za/rhp.

BOTES PJ and VAN STADEN JF (2005) Investigation of trace element mobility in river sediments using ICP-OES. Water SA 31 (2) 183-191.

CHEN J-C. and LIN C-H. (2001) Toxicity of copper sulphate for survival, growth, molting and feeding of juveniles of the tiger shrimp, Penaeus monodon. Aquacult. 192 (1) 55-65.

DWA (2009) Department of Water Affairs - Resource Quality Services. http://www.dwaf.gov.za/iwqs.wms/index.asp (Accessed on 1 October 2009).

DWAF (1996a) South African Water Quality Guidelines (1 $1^{\text {st }}$ edn.) Vol. 8: Field Guide. Department of Water Affairs and Forestry, Pretoria, South Africa.

DWAF (1996b) South African Water Quality Guidelines. Vol. 7: Aquatic Ecosystems. Department of Water Affairs and Forestry, Pretoria, South Africa.

HAMMARSTROM JM, SEAL RR, MEIER AL and KORNFELD JM (2005) Secondary sulfate minerals associated with acid mine drainage in the eastern US: recycling of metals and acidity in surficial environments. Chem. Geol. 215 407-431.

KEMPSTER PL, SILBERBAUER M and KÜHN A (2007) Interpretation of drinking water quality guidelines - The case of arsenic. Water SA 33 (1) 95-100.

MAJER V, KRÁM P and SHANLEY JB (2005) Rapid regional recovery from sulfate and nitrate pollution in streams of the western Czech Republic - comparison to other recovering areas. Environ. Pollut. 135 17-28.

MINISTRY OF ENVIRONMENT, LANDS and PARKS, PROVINCE OF BRITISH COLUMBIA (2000) Ambient Water Quality Guidelines for Sulphate http:/Www.env.gov.bc.ca/wat/wq BCguidelines/sulphate (Accessed on 1 October 2009).

MONTEITH DT and EVANS CD (2005) The United Kingdom Acid Waters Monitoring Network: a review of the first 15 years and introduction to the special issue. Environ. Pollut. 137 3-13.

NAICKER K, CUKROWSKA E and McCARTHY TS (2003) Acid mine drainage arising from gold mining activity in Johannesburg, South Africa and environs. Environ. Pollut. 122 29-40.

PALABORA MINING COMPANY (LTD.) (2005) Underground Mining http://www.palabora.com/Default.aspx?page $=105$ (Accessed on 1 October 2009)

REARDON IS and HARRELL RM (1990) Acute toxicity of formalin and copper sulphate to striped bass fingerlings held in varying salinities. Aquacult. 87 (3/4) 255-270. 
STATUTES OF THE REPUBLIC OF SOUTH AFRICA -

CONSTITUTIONAL LAW (1996) Constitution of the Republic of South Africa Act No. 108 of 1996. http://www.info.gov.za/documents/constitution/1996/a108-96.pdf (Accessed on 30 September 2009).

TAYLOR RM, WATSON GD and ALIKHAN MA (1995) Comparative sub-lethal and lethal acute toxicity of copper to the freshwater crayfish, Cambarus robustus (Cambaridae, Decapoda, Crustucea) from an acidic metal-contaminated lake and a circumneutral uncontaminated stream. Water Res. 29 (2) 401-408.
TORRES P, TORT L and FLOS R (1987) Acute toxicity of copper to Mediterranean dogfish. Comp. Biochem. Physiol. Part C: Comp. Pharmacol. 86 (1) 169-171.

VAN VUUREN L (2009) Experts unite to save abused river from extinction. The Water Wheel Jan/Feb 14-17.

WHO (World Health Organisation) (2004) Guidelines for DrinkingWater Quality (3 ${ }^{\text {rd }}$ edn.) Vol. 1 Recommendations. WHO, Geneva, Switzerland $515 \mathrm{pp}$ 